International Journal of Agriculture and Environmental Research

ISSN: 2455-6939

Volume: 07, Issue: 03 "May-June 2021"

\title{
STUDY ON FINANCIAL STRATEGY EVALUATION OF Q\&K INTERNATIONAL GROUP
}

\author{
${ }^{1}$ Aifang Gao, ${ }^{2 *}$ Xuan Zheng \\ ${ }^{1}$ Lecturer, Ginling College, Nanjing Normal University, Nanjing, China \\ ${ }^{2}$ Undergraduate, Ginling College, Nanjing Normal University, Nanjing, China \\ *Corresponding Author
}

DOI: https://doi.org/10.51193/IJAER.2021.7310

\begin{abstract}
With the supports of national policy, the housing rental market in China has developed rapidly in the past ten years, and the new industries such as long-rent apartments have begun to appear in the three-level real estate market. At present, there are more than 1000 existing long-rent apartment enterprises in our country. Among them, Q\&K International Group , as the leading industry, went to the United States for IPO in October 2019, but in 2020, it fell into financial difficulties such as rent loan thunderstorm, capital chain breakage, platform roll money running away. Taking Q\&K International Group as an example, this paper analyzes the problems existing in its management, financing and investment strategy, uses the three-dimensional financial matrix model to evaluate the effect of its financial strategy implementation, and puts forward some suggestions to optimize its financial strategy, which also provides reference for the development of enterprises in the same industry.
\end{abstract}

Keywords: Long - term rental apartment, financial strategy evaluation, 3D matrix model

\section{INTRODUCTION}

Driven by macro policy orientation and rental demand, the long-rent apartment market has developed rapidly in the past five years, attracting the favor of capital from all walks of life. Although long-rent apartments have a trillion-level market to be developed, in the face of the sudden risks outbreak and increasingly competitive industry environment, more than 30 parent rental apartment operators have closed down in 2020, even the industry giant Q\&K International Group and Eggshell Apartments could no survive. Many scholars have studied the problems 
involved in long-rent apartments, but most of them focus on the financing mode, operation mode, risk control and other fields. There is little research on the choice or evaluation of financial strategy.

Q\&K International Group is Shanghai Q\&K International Group Equipment Leasing Co., Ltd., founded in 2012, is a state-owned background, employee ownership of mixed ownership enterprises. Since its establishment, Q\&K International Group has developed rapidly and its business scope covers many cities in China. In October 2019, Q\&K International Group was listed on NASDAQ, becoming the first long-rent apartment brand to be listed overseas in China. However, a sudden outbreak of epidemic situation in 2020 caused the long-rent apartment industry to fall into a "cold winter ". Q\&K International Group was influenced by "default landlord rent, defrauded rent loan, capital chain break, platform closure run away" and other negative news. The fundamental reason is that the long-rent apartment enterprises choose inappropriate financial strategy to lead to the difficulty of capital turnover. This article will mainly introduce and analyze the issues from three angles: business strategy, financing strategy and investment strategy.

\section{A BRIEF INTRODUCTION TO THE FINANCIAL STRATEGY OF Q\&K INTERNATIONAL GROUP}

\subsection{Focus on Distributed Leasing and Slow Down Heavy Asset Expansion}

For long-rent apartment enterprises, housing is the most important resource. There are two ways to obtain the sources of the long rental apartment, one is to obtain the ownership and management right of the whole house by means of construction, purchase, lease and so on, and the other is to rent the distributed long rental apartment through the integration, decoration and renovation of different buildings in different areas.

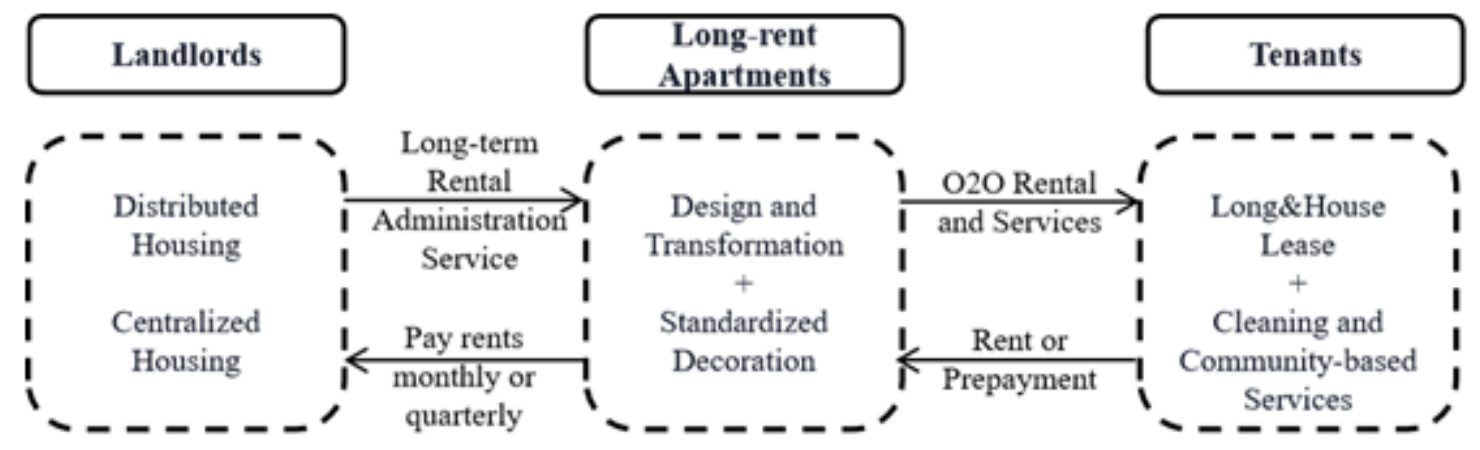

Fig. 1: Operation mode of long-rent apartment 
According to figure 1, Q\&K International Group belongs to the long-rent apartment enterprise which is mainly distributed and centralized, usually collects the house sources information from the traditional real estate intermediary or the online platform first, then carries on the offline house viewing with the landlord, negotiates and signs the contracts with them. Distributed and centralized long-rent apartments have their own advantages and disadvantages. The former has a small scale of pre-investment funds, more and to housing, but the standardization level is not high, the management cost is high, and it is not conducive to the development of communitybased services.

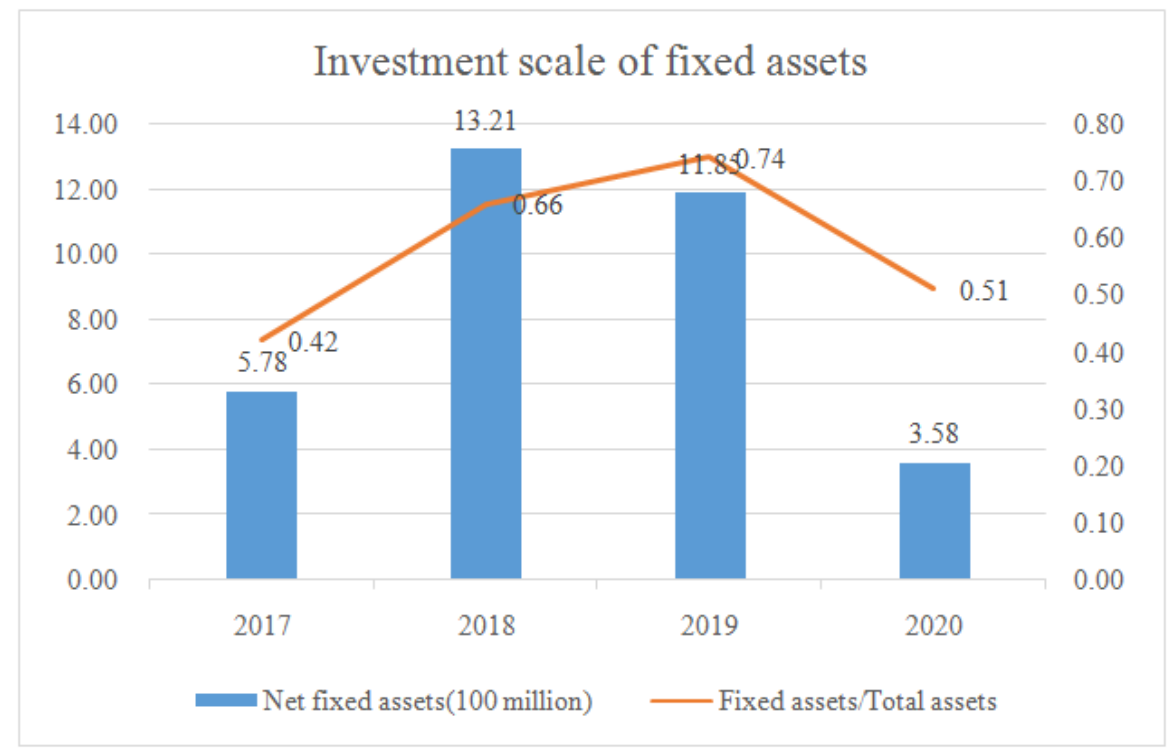

Fig. 2: The investment scale of fixed assets in 2017-2020 of Q\&K International Group

Data source: 2017 - 2020 Annual Report of Q\&K International Group

Although Q\&K International Group only has the right to lease most of its housing resources, its asset model is still heavy asset. It can be seen from Figure 2 that the proportion of fixed assets to total assets continued to be high from 2017- 2019, indicating that it has a high investment in long-term assets such as building, decoration, furniture and equipment. However, in 2020, it's overall size of fixed assets declined by $70 \%$, accounting for $42 \%$ of the total assets, thus slowing down the expansion of Q\&K International Group in the heavy asset model.

\subsection{Diversified Financing Approaches "Rent Loans" Account for a Relatively High}

Since its establishment in 2012, Q\&K International Group has obtained abundant financial support through diversified financing channels, mainly including equity financing, asset 
securitization, financing after - sale and lease back, issuance of convertible bonds and other ways.

During its start-up period, the company was funded mainly through private equity, and then completed its IPO in 2019. Up to now, the equity financing scale of Q\&K International Group has been nearly 970 million yuan it also carries on financing through asset securitization. In 2017, it and Lujiazui International Trust Co., Ltd. set up a fund trust plan, the tenant accounts receivable as the proceeds of the pledge, received 10 million yuan of financial support.

Although the company adopts a diversified financing strategy, most of its funds depend on rental loan financing. "Rent loan" means that the tenant and the company signed a rental contract for more than 2 years, can rely on the platform of the company to apply for credit loans to banks and other financial institutions, financial institutions will be a one-time loan to the company account, Tenants only ensure monthly rent to be paid to the bank. The cost of obtaining future rental income cash flow in advance is only to pay a certain interest to the bank. According to the 2019 prospectus, Q\&K booked $65.2 \%$ of the funds used the "rent loan ".

\subsection{Investment and M\&A to Accelerate the Distribution of Housing Network}

The enterprise investment strategy is to reasonably allocate the capital and resources held by the enterprise according to the requirements of the overall enterprise operation strategy, and connect it with the investment effect, which is divided into two categories of internal investment and external investment. As a long-term rental apartment enterprise, external investment is mainly equity investment, merger and acquisition investment, etc., and internal investment is mainly fixed assets, namely rental housing .

In terms of external investment, since its establishment, Q\&K International Group has successively injected equity of 1.4 billion yuan in 17 companies in the leasing and business services, real estate, wholesale and retail, accommodation and catering industries. This explosive growth began to slow down in 2019. After the completion of it's IPO, Q\&K International Group has acquired long - term apartment assets in Tianjin, Sichuan, Chongqing and other places, totally of 121,000 rental houses.

Under the influence of the epidemic situation, the market economy of long apartments as a whole presents a decline trend, a large number of long-rent apartment enterprises housing rental rate significantly decreased, into a profit dilemma, faced with a broken capital chain, thunderstorm incidents occurred frequently. Q\&K International Group but reverse trend, even in the state of sustained loss, still choose expansion investment strategy; take advantage of the industry's overall housing vacancy rate rise, low rent to buy competitors' sites. 


\section{FINANCIAL STRATEGY EVALUATION OF Q\&K INTERNATIONAL GROUP BASED ON 3D FINANCIAL MATRIX MODEL}

As shown in Figure 3, this article constructs a 3D financial strategy matrix model with capital status, economic value and operating risk, and the axis $\mathrm{X}$ represents the capital situation, namely poor growth rate; the $\mathrm{Y}$ axis represents economic value, the deviation of rate of return, the $\mathrm{Z}$ axis represents operating risk, the operating leverage risk factor. As shown in Table 3.1, the matrix divides the enterprise's financial strategies into eight different matrix states.

\section{Fig. 3: Three-dimensional financial matrix model}

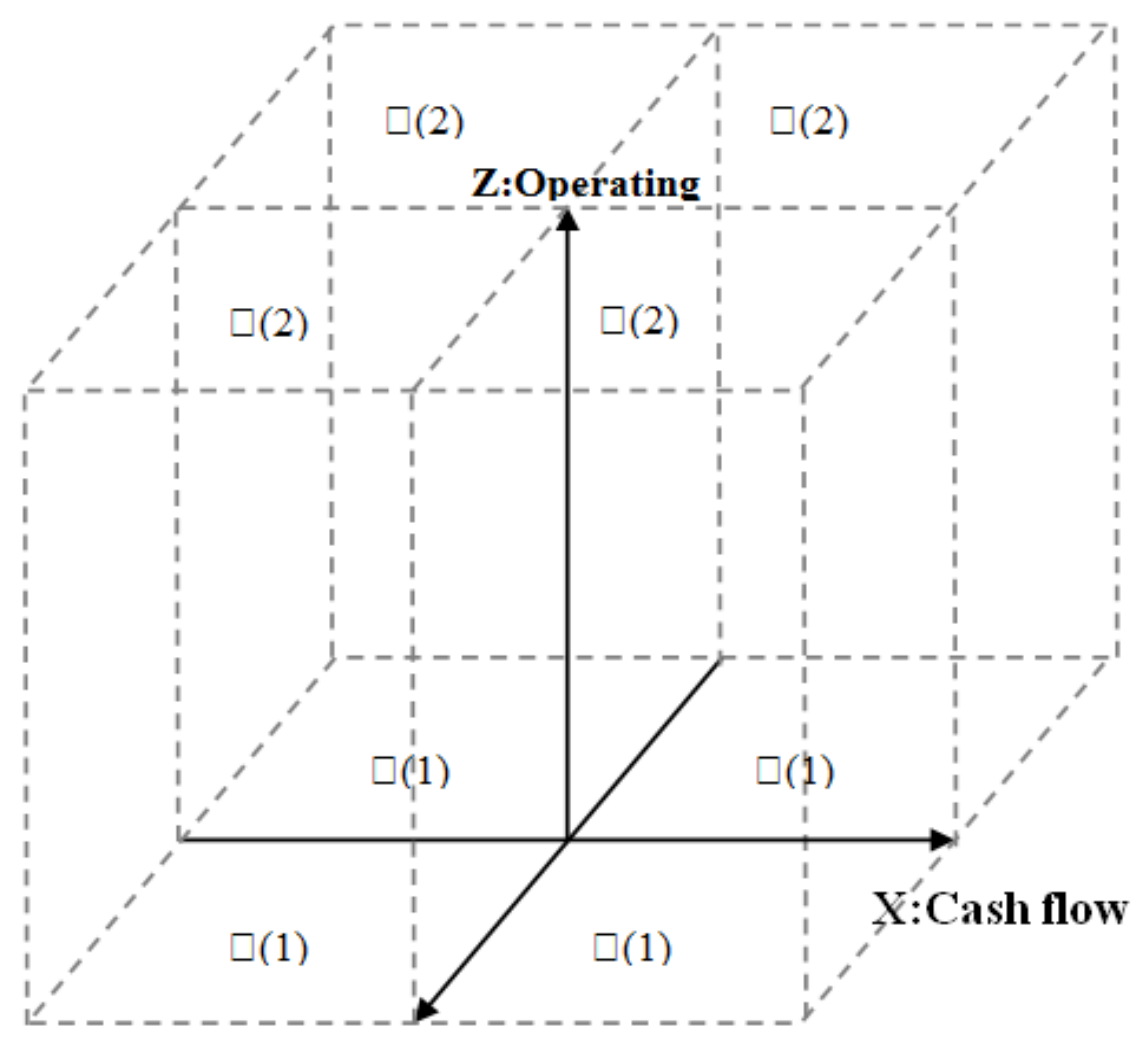

Y:Economic 
International Journal of Agriculture and Environmental Research

ISSN: 2455-6939

Volume: 07, Issue: 03 "May-June 2021"

Table 1: Quadrant status of 3D financial matrix

\begin{tabular}{|c|l|}
\hline Quadrant & \multicolumn{1}{|c|}{ Status } \\
\hline \multirow{2}{*}{ First Quadrant } & (1) Value type, cash surplus, low operating risk \\
\cline { 2 - 2 } & (2) Value type, cash surplus, high operating risk \\
\hline \multirow{2}{*}{ Second Quadrant } & (1) Value type, cash shortage, low operating risk \\
\cline { 2 - 2 } & (2) Value type, cash shortage, high operating risk \\
\hline \multirow{2}{*}{ Third Quadrant } & (1) Derogation type, cash shortage, low operating risk \\
\cline { 2 - 2 } & (2) Derogation type, cash shortage, high operating risk \\
\hline \multirow{2}{*}{ Forth Quadrant } & (1) Derogation type, Cash surplus, low operating risk \\
\cline { 2 - 2 } & (2) Derogation type, Cash surplus, high operating risk \\
\hline
\end{tabular}

Specifically, the calculation process of the three dimensions is as follows:

$\mathrm{X}($ financial situation $)=\mathrm{X} 1($ income growth $)-\mathrm{X} 2($ sustainable growth $)$

$=($ current period income-previous period income $) /$ previous period incomenet sales profit rate $\times$ total asset turnover $\times$ equity multiplier $\times$ retention rate $\quad$...Formula 1

$\mathrm{Y}($ economic value $)=\mathrm{Y} 1(\mathrm{ROI})-\mathrm{Y} 2$ (weighted average cost-of-capital ratio)

$=$ Post - Tax Net Operating Profit $/$ Initial Total Assets - [Equity Capital Cost $\times$ Equity Capital / Total Assets + Debt Capital Cost $\times$ Debt Capital / Total Assets $\times(1$ - Income Tax Rate) $]$ Formula 2

$\mathrm{Z}($ operating risk $) \quad=\mathrm{DOL}$ (operating leverage coefficient $)=\Delta \mathrm{EBIT} / \Delta \mathrm{Q}$

= Sales Revenue - Variable Cost $/($ Sales Revenue - Variable Cost - Fixed Cost) Formula 3

The financial data and relevant public data disclosed by Q\&K International Group over the years can calculate the above indicators, so as to build the financial strategy matrix over the years, and quantitatively evaluate the effect of the implementation of its financial strategy. 
International Journal of Agriculture and Environmental Research

ISSN: 2455-6939

Volume: 07, Issue: 03 "May-June 2021"

\subsection{Evaluation Index and Data Processing of 3D Financial Strategy Matrix Model}

In the capital dimension, as shown in Table 2, the difference between the income growth rate and the sustainable growth rate is built to determine that the capital state is in shortage or surplus. According to the financial data of Q\&K International Group, the relevant indicators of poor growth rate are calculated as follows:

Table 2: Financial data and related indicators of Q\&K International Group 2017-2020, Unit: CNY

\begin{tabular}{|l|r|r|r|r|}
\hline Financial Indicators & 2017 & 2018 & 2019 & 2020 \\
\hline Business Income & $522,737,000$ & $889,937,000$ & $1,233,770,000$ & $1,207,963,000$ \\
\hline Income growth rate (\%) & - & 70.25 & 38.64 & -2.09 \\
\hline Sales profits rate (\%) & -46.95 & -56.17 & -40.39 & -126.96 \\
\hline Total assets turnover & 0.46 & 0.61 & 0.69 & 0.91 \\
\hline Total assets & $1,133,598,000$ & $1,781,403,000$ & $1,799,746,000$ & $850,730,000$ \\
\hline Total equity & $-425,970,000$ & $-779,134,000$ & $-810,866,000$ & $-1,994,450,000$ \\
\hline Equity multiplier & -2.66 & -2.29 & -2.22 & -0.43 \\
\hline Undistributed profit & $-304,203,000$ & $-635,467,000$ & $-805,726,000$ & $-1,533,641,000$ \\
\hline Net Profit & $-245,440,000$ & $-499,922,000$ & $-498,337,000$ & $-1,533,641,000$ \\
\hline Retained Earning rate $(\%)$ & 123.94 & 127.11 & 161.68 & 100.00 \\
\hline Sustainable growth & & & & 100.01 \\
rate (\%) & - & 99.59 & -61.38 & 49.28 \\
\hline Growth rate difference (\%) & - & -29.34 & & -51.37 \\
\hline
\end{tabular}

Data source: 2017-2020 Annual Report of Q\&K International Group

In the value dimension, as shown in Table 3, the value creation ability of the enterprise is equal to the net profit after tax minus the total capital cost of the enterprise, which is expressed by the ratio index, that is, the return on investment minus the weighted average capital cost rate. When calculating the ROI, the operating profit should be adjusted to the net operating profit after tax, that is, the operating profit plus the financial expense multiplied by 1 minus the difference of income tax rate, then minus the income tax expense, and then divided by the total assets to get the ROI. The cost rate of equity capital is calculated from the capital asset pricing model, which is equal to the risk-free interest rate plus beta coefficient multiplied by the difference between the 
market rate of return and the risk-free interest rate. In order to facilitate the calculation, this paper uses the 2016-2020 Nasdaq stock composite price index to calculate the geometric average yield, and uses the 10-year Treasury bond interest rate to express the risk-free interest rate. In addition, the beta coefficient is used to measure the price fluctuation of a single stock relative to the whole stock market, while the green guest is listed in 2019, so the relevant data queried in Tonghuashun platform is used to replace the beta coefficient of 2017-2020. The process of adjustment and calculation is as follows:

Table 3: Financial data and related indicators of Q\&K International Group 2017-2020, Unit: CNY

\begin{tabular}{|l|r|r|r|r|}
\hline Financial indicators & 2017 & 2018 & 2019 & 2020 \\
\hline Business profit & $-239,682,000$ & $-503,602,000$ & $-540,221,000$ & $-1,630,983,000$ \\
\hline Financial expenses & $-50,136,000$ & $-77,167,000$ & $-91,914,000$ & $-130,206,000$ \\
\hline Income tax & 596,000 & $2,393,000$ & 63,000 & 13,000 \\
\hline After-tax net business profit & $-277,880,000$ & $-563,870,250$ & $-609,219,500$ & $-1,728,650,500$ \\
\hline Total assets & $1,133,598,000$ & $1,781,403,000$ & $1,799,746,000$ & $850,730,000$ \\
\hline ROI (\%) & - & -49.74 & -34.20 & -96.05 \\
\hline Equity capital & $-425,970,000$ & $-779,134,000$ & $-810,866,000$ & $-1,994,450,000$ \\
\hline Debt capital & $1,559,568,000$ & $2,560,537,000$ & $2,610,612,000$ & $2,845,180,000$ \\
\hline Equity Capital/Total Assets & -37.58 & -43.74 & -45.05 & -234.44 \\
\hline Debt capital/Total assets & 137.58 & 143.74 & 145.05 & 334.44 \\
\hline Average market earning rate (\%) & 27.56 & 21.38 & 16.84 & 19.17 \\
\hline Risk free interest rate (\%) & 2.33 & 2.91 & 2.14 & 0.89 \\
\hline$\beta$ & 12.6 & 12.6 & 12.6 & 12.6 \\
\hline Risk premium (\%) & 25.24 & 18.47 & 14.71 & 18.28 \\
\hline Equity capital cost rate (\%) & 320.29 & 235.62 & 187.45 & 231.17 \\
\hline Non-current liability & $386,389,000$ & $590,654,000$ & $913,501,000$ & $883,440,000$ \\
\hline Debt capital cost rate(\%) & 12.98 & 13.06 & 10.06 & 14.74 \\
\hline WACC (\%) & - & 34.53 & 35.66 & 396.61 \\
\hline Return rate difference (\%) & - & 52.62 & 36.01 & 289.46 \\
\hline Data source: $2017-2020 A n n$ & & & \\
\hline
\end{tabular}

Data source: 2017 - 2020Annual Report of Q\&K International Group

In the risk dimension, as shown in Table 4, the operating leverage coefficient is used to represent the operating risk of Q\&K International Group. According to the published information, it is 
difficult to query the financial data such as the whole variable cost and fixed cost.

Table 4: Financial data and related indicators of Q\&K International Group 2017-2020

\begin{tabular}{|l|r|r|r|r|}
\hline Indicators & 2017 & 2018 & 2019 & 2020 \\
\hline$\Delta$ EBIT $(\%)$ & - & -102.92 & -8.04 & -183.75 \\
\hline$\Delta$ Q $(\%)$ & - & 70.25 & 38.64 & -2.09 \\
\hline DOL & - & -1.465 & -0.21 & 87.84 \\
\hline
\end{tabular}

\subsection{Evaluation results of the three-dimensional financial strategy matrix model}

(1) Revenue growth fell sharply, insufficient liquidity in capital

According to the index results of capital dimension, the operating revenue of Q\&K International Group maintained a good growth in the first three years, with the operating income of 1.208 billion yuan in 2020, a decrease of $2.09 \%$ on the last year. From Fig.3.2, the income growth rate of Q\&K International Group has declined in the past four years, especially in 2020 affected by COVIC-19 epidemic situation, the company lost many customers, but the fixed expenditure did not decrease, resulting in its operating profit and net profit loss.

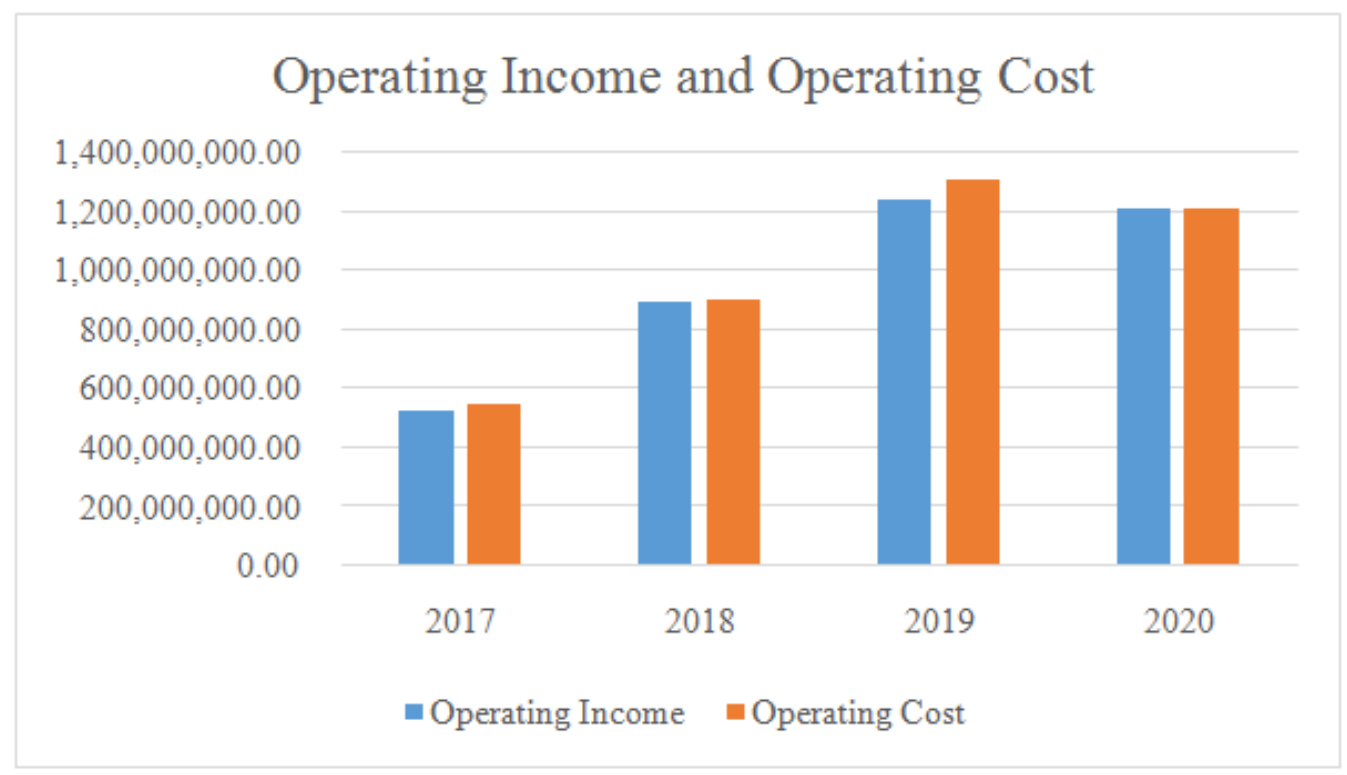

Fig. 4: Q\&K International Group Operating Income and Operating Cost from 2017 -2020

Data source: 2017 - 2020 Annual Report of Q\&K International Group 
International Journal of Agriculture and Environmental Research

ISSN: 2455-6939

Volume: 07, Issue: 03 "May-June 2021"

According to formula 1, the sustainable growth rate of Q\&K International Group can be calculated, and the growth rate difference is $-29.34 \%,-61.38 \%,-51.37 \%$ between $2018-2020$. Overall, the growth rate of operating income is far below the sustainable growth rate that can be achieved without changing the existing financial policy and capital structure, which indicates that Q\&K International Group is in a state of shortage of funds for a long time.

(2) Overall profitability, insolvent successive losses

Q\&K International Group has been in an insolvent state in the past four years. Although the diversified financing model has brought considerable cash flow, these financing models have certain limitations. Although equity financing reduces capital costs, it is not conducive to mastering the business control of the enterprise. The interest cost borne by financing lease back is relatively low but the financing cycle is short and the financing amount is limited The cost of rental loan and crowd funding is high, and there is a lack of supervision and norms of the market and industry, and the liquidity risk of capital is large, which is not suitable as the main financing model.

(3) Business leverage coefficient is too high, their own business risk rises

In the risk dimension, $\mathrm{Q} \& \mathrm{~K}$ International Group faces high operating risks, According to figure 3.3, DOL was negative in 2018 and 2019, By 2020, it had risen sharply to 87.85. The literature suggests, according to the DOL of the enterprise belongs to the interval to divide the business state, as shown in table 4, when the DOL is negative, It shows that the enterprise is in a state of loss and operation is extremely dangerous, At this point, the increase in sales will lead to lower profits, According to formula 3, it can be inferred that the fixed cost of depreciation and amortization, wages and advertising expenses of Q\&K International Group is higher, this leads to higher operating leverage. The company's total assets turnover rate has been rising in the past four years, because its total assets fell more than sales revenue, does not mean that its own assets operating efficiency. Although the company's DOL changed from negative to positive in 2020, but actual situation is far lower than the safety level, The DOL became positive just because the molecular $\Delta \mathrm{Q}$ and denominator of the DOL formula are both negative, does not mean that the company's operating conditions in 2020 has improved. 
International Journal of Agriculture and Environmental Research

ISSN: 2455-6939

Volume: 07, Issue: 03 "May-June 2021"

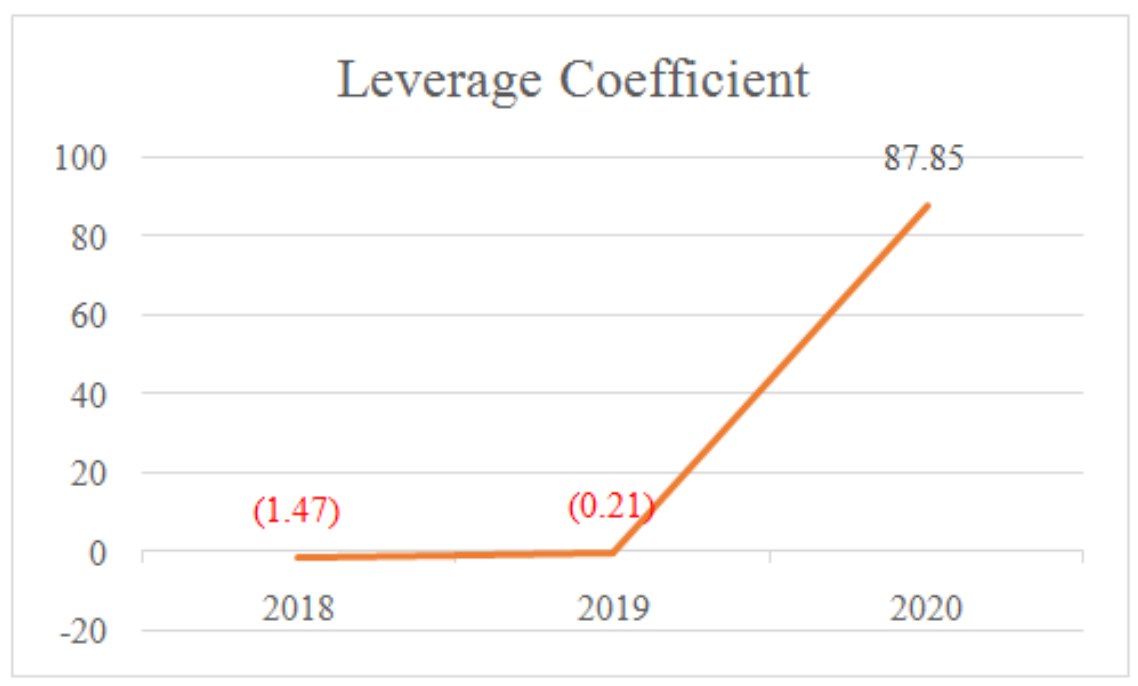

Fig. 5: Leverage Coefficient of Q\&K International Group, 2018-2020

Note: Because the financial data of Qingke Company from 2017 -2020 can only be inquired according to the public data, the operating leverage coefficient index cannot be calculated in 2017

Table 5: Relationship between Business Leverage Coefficient and Business Status

\begin{tabular}{|l|l|}
\hline DOL & Status \\
\hline DOL $>10$ & Very Dangerous \\
\hline $6.6 \leqslant \mathrm{DOL} \leqslant 10$ & More dangerous \\
\hline $4 \leqslant \mathrm{DOL}<6.6$ & Not good \\
\hline $3 \leqslant \mathrm{DOL}<4$ & Saf ure \\
\hline $1 \leqslant \mathrm{DOL}<3$ & Safe \\
\hline $0 \leqslant \mathrm{DOL}<1$ & N/A \\
\hline $\mathrm{DOL}<0$ & Extremely Dangerous \\
\hline
\end{tabular}

To sum up, Q\&K International Group was located in the third quad rant from 2017 to 2020, value impairment, shortage of funds, and high operating risk. Whether analyzed from a single dimension or the whole, the past and current financial strategy of Q\&K International Group did not play its due role, and the allocation of overall resources of the enterprise hardly created or realized value for the enterprise. At this point, the financial strategy of Q\&K International Group failed. However, to investigate reason of the failure is mainly due to the root defects of the business model of the long - term rental apartment industry. The long - term rental apartment 
industry generally relies on the heavy - asset mode, and needs to invest a large amount of idle land and housing resources in the early development, and then relies on the anti - commercial behavior of "high income and low rent, long - term collection and short payment" to expand the business scale. Once there are factors affecting the cash flow, it will lead to the tension or even rupture of the cash flow.

\section{SUGGESTIONS ON IMPROVING FINANCIAL STRATEGY OF Q\&K INTERNATIONAL GROUP}

According to the analysis results of the 3D financial strategy matrix model, Q\&K International Group was in the third quad rant of the financial strategy matrix from 2017-2020: value impairment, shortage of funds and high business risk. In view of this, the following recommendations for the future financial strategy:

\subsection{Vertical Development of Leasing Services to Optimize Existing Asset Structures}

Cash flow is the blood of the survival and development of enterprises, and a major defect in the business model of long-rent apartment enterprises is that the difference in rent transfer under the heavy asset model will bring great financial pressure. Increasing the number of housing sources is an important measure for the rapid expansion of business scale of long-rented apartments, but pay attention to "quantitative change" and should also pay attention to "qualitative change". Only by providing more, better and more secure housing rental services for tenants can they be based on the forefront of the industry.

Combined with the development experience enterprises in the same industry, Q\&K International Group can improve the asset structure by vertically integrating the light assets model of leasing and service business. Some cities with high vacancy rates can be transferred to third-party agencies to establish new partnerships with tenants, while the company is only responsible for operating services.

\subsection{Matching the Rent Collection and Payment Cycle to Strengthen Cooperation Financing}

The inappropriate financing methods and the too high proportion of rent and loan financing bring large financial risks to Q\&K International Group. According to the latest policy of housing rental in Shanghai, Beijing and Shenzhen, Housing and Urban-Rural Development Commission Departments have clearly stipulated that the amount of housing rental enterprises should be less than three months, and bank financial institutions shall not allocate rent loans to housing rental enterprises. Therefore, the author suggests that Q\&K International Group should match the rent collection and payment cycle, in order to prevent the liquidity risk brought by "long term income 
and short term payment".

On the other hand, drawing lessons from the experience of other players in the industry and considering the guidance of the current national policies, Q\&K International Group should strengthen the financing cooperation with the financing institutes. Q\&K International Group can sell purchased furniture and equipment to the financing institutes and rent back, allowing significant savings on operating costs and improving net operating margins.

\subsection{Grasp the Opportunity of Industry Policy, Quickly Improve Performance}

The national policy pays special attention to the problem of "people's living" in the top-level design, to strengthens the concentration of the housing rental industry, promulgates plans to promote the standardized development of the housing rental market, and introduces relevant preferential policies to encourage the concept of rental consumption. To fully understand the policies is the critical step to grasp the markets and customers.

Make full use of Information technology to improve service and efficiency and effectiveness, obtain housing data resources and transaction data through information platform, combine big data technology to analyze business growth point and customer preference and behavior, and provide more accurate and high quality service for tenants.

\section{REFERENCES}

[1] Chen Qiuzhu, Deng Ruohan. "Rent loan" of long-term rental apartment: problem inspection, causes and regulatory path J. Southern Finance, 2019(04):91-98.

[2] The snow snowed. Research on Financial Strategic Management Based on Enterprise Life Cycle D. Shandong University, 2017.

[3] Duan Xiaoyan. A study on financial strategy selection of long-rent apartment enterprises based on enterprise life cycle D. Yunnan University of Finance and Economics, 2019.

[4] He Youneng. Case Study of China D. Guangdong University of Finance and Economics, 2019.

[5] Li Xiaolin. China's long-rent apartment industry financing model research D. East China Normal University, 2018.

[6] Li Xin. Research on Full Life Period Risk Management of Long - term Rental Apartment Project D. Qingdao University of Technology, 2019. 
[7] Liu Zhuo. Thoughts and Suggestions on the Development of Long-term Rental Apartment Market in China: J. China Construction Information Technology, 2017(13):7273.

[8] Hu Zhenghua. The value of the new model of "Internet long rental apartment" discusses A. China Society of Real Estate Appraisers and China Real Estate Valuation and Brokers Issue 3, 2015 (Total Issue 11 2) C. China Society of Real Estate Apprais ers and Real Estate Agents : China

[9] Huang Yanfen, Wang Chunxi, Zhang Chao, Chen Xiangyun. To establish a long-term mechanism for the development of China's housing rental market — to promote the J. price theory and practice with the same right of rent and purchase, 2017(10):17-21.

[10] Wang Kebei. Evaluation of Su Ning's Financial Strategy Based on 3D Matrix Model of Financial Strategy J. Monthly Journal of Science and Technology Entrepreneurship, 2016, 29(06):48-51.

[11] Wang Jianhong. A Study on the Present Situation, Problems and Countermeasures of the Development J. Residential and Real Estate, 2016(33):237+240.

[12] Xu Zhenning. A Study on Financial Strategy Evaluation of Futian Automobile Based on Three-dimensional Strategic Matrix Model D. Jiangxi Normal University, 2020.

[13] Yan $\mathrm{Ru}$, Jiang Guoping .Research on J. operation and management of long - term rental apartment business model innovation based on competitive advantages , 2020(04):64-68.

[14] Yang Yijia. A Study on Risk Control of Long Renting Apartment Business D. Xiamen University, 2018.

[15] Zhang Huibin. A Study on the Business Model of Service style Long Rent Apartments Based on Real Estate Enterprises D. Guangdong University of Technology, 2018. 